\title{
BLOOD-LEAD LEVELS OF FALL MIGRANT GOLDEN EAGLES IN WEST-CENTRAL MONTANA
}

\author{
Robert DomeneCh ${ }^{1}$ ANd HeIko LANGNeR ${ }^{2}$ \\ ${ }^{I}$ Raptor View Research Institute, P.O. Box 4323, Missoula, MT 59806, USA. \\ E-mail: rob.domenech@raptorview.org \\ ${ }^{2}$ University of Montana, Geosciences Department, Missoula, MT 59812, USA.
}

\begin{abstract}
EXTENDED ABSTRACT.- Lead has long been documented as a serious environmental hazard to eagles and other predatory and scavenging avian species (Redig et al. 1984, Kramer and Redig 1997). The use of lead shotgun pellets for waterfowl hunting on federal and state lands was banned in 1991 due to lead poisoning in Bald Eagles (Haliaeetus leucocephalus), Golden Eagles (Aquila chrysaetos) and numerous waterfowl species. Spring migrating eagles sampled in west-central Montana between 1983 and 1985 showed elevated blood-lead levels in $85 \%$ of 86 Golden Eagles and $97 \%$ of 37 Bald Eagles (Harmata and Restani 1995). The authors suggested shot from waterfowl hunting and fragmented lead-core rifle bullets in ground squirrels (Spermophilus spp.) as a possible lead source. More recently, lead poisoning from spent ammunition has been identified as the leading cause of death in California Condors (Gymnogyps californianus), prompting the recent ban of lead ammunition within the "California Condor Recovery Zone" (Hunt et al. 2006, Cade 2007). Another study on Common Ravens (Corvus corax) in Wyoming has shown a direct correlation between elevated bloodlead levels and the onset of rifle hunting season (Craighead and Bedrosian pers. comm.)
\end{abstract}

We sampled blood from 42 Golden Eagles captured on migration during the fall of 2006 and 2007 to quantify a suite of possible heavy metal contaminants, with an emphasis on lead. Eagles were trapped using traditional ridgeline trapping techniques with bow nets, and using a harnessed Rock Dove (Columbia livia) for a lure (Bloom 1987).
Small blood samples $(2 \mathrm{ml})$ were taken from the brachial vein, and whole blood samples $(1 \mathrm{ml})$ were frozen for later analysis using Inductively Coupled Plasma-Mass Spectrometry (ICP-MS) following hot acid digestion. We employed a portable field instrument (ESA LeadCare II ${ }^{\circledR}$, Biosciences Inc.) to analyze lead in a subset of 20 samples. Our data suggest that both methods produce equivalent results.

Total lead concentrations ranged from $<0.5$ to 481 $\mu \mathrm{g} / \mathrm{dL}$ with a median value of $13.6 \mu \mathrm{g} / \mathrm{dL}$. When separated into four exposure stages (Redig 1984), our results were as follows: 18 eagles contained background levels of $0-10 \mu \mathrm{g} / \mathrm{dL}, 19$ eagles were considered sub-clinically exposed at 10-60 $\mu \mathrm{g} / \mathrm{dL}$, two birds were clinically exposed (60-100 $\mu \mathrm{g} / \mathrm{dL})$, and three exhibited acute exposure of $>100 \mu \mathrm{g} / \mathrm{dL}$. In all, we found that $58 \%$ of the 42 fall migrant Golden Eagles sampled had elevated blood-lead levels.

We speculate that the five birds (12\%) showing at least clinical exposure levels $(\geq 60 \mu \mathrm{g} / \mathrm{dL}$ ) had recently ingested lead-tainted carcasses and/or offal piles, likely during migration. Eagles with lower, but detectable blood lead levels may have had earlier exposure with the majority of the lead already deposited in other organs and bone. We surmise the use of lead-core ammunition for hunting is the major source for lead exposure in Golden Eagles, though we cannot identify a particular source species or region, in part because of the overlapping timing of hunting seasons for various game species in different regions of the Rocky Mountains and the 


\section{- DOMENECH AND LANGNER -}

very large area visited by Golden Eagles during migration season.

We are uncertain whether our preliminary numbers represent the northern migratory population of Golden Eagles as a whole, but a serious threat to the welfare of the species on a landscape level ap- pears plausible. We believe an intensive educational outreach campaign and a switch away from lead-containing hunting ammunition to alternative, less toxic materials are appropriate ways to protect these and other scavenging species, as well as human consumers of gun-killed animals. Received 5 September 2008, accepted 17 November 2008.

DOMENECH, R., AND H. LANGNER. 2009. Blood-lead levels of fall migrant Golden Eagles in west-central Montana. Extended abstract in R. T. Watson, M. Fuller, M. Pokras, and W. G. Hunt (Eds.). Ingestion of Lead from Spent Ammunition: Implications for Wildlife and Humans. The Peregrine Fund, Boise, Idaho, USA. DOI 10.4080/ilsa.2009.0210

Key words: Fall migration, Golden Eagle, lead poisoning, Rocky Mountains.

\section{LITERATURE Cited}

BLoOM, P. H. 1987. Capturing and Handling Raptors. Pages $99-123$ in B. A. Millsap, K. W. Cline, B. G. Pendleton, and D. A. Bird (Eds.). Raptor Management Techniques Manual. National Wildlife Federation, Washington, DC, USA.

CADE, T. J. 2007. Exposure of California Condors to lead from spent ammunition. Journal of Wildlife Management 71(7):2125-2133.

Harmata, A. R., AND M. ReStani. 1995. Environmental contaminants and cholinesterase in blood of vernal migrant Bald and Golden Eagles in Montana. Intermountain Journal of Sciences $1: 1-15$.
Hunt, W. G., W. Burnham, C. N. Parish, K. K. Burnham, B. Mutch, AND J. L. OAKS. 2006. Bullet fragments in deer remains: implications for lead exposure in avian scavengers. Wildlife Society Bulletin 34:167-170.

Kramer, J. L., AND P. T. Redig. 1997. Sixteen years of lead poisoning in eagles, 1980-95: an epizootiologic view. Journal of Raptor Research 31:327-332.

REDIG, P. T. 1984. An investigation into the effects of lead poisoning on Bald Eagles and other raptors: final report. Minnesota Endangered Species Program Study 100A-100B, University of Minnesota, St. Paul, Minnesota, USA. 